\title{
(IbM) DENGAN METODE GERAKAN PERSENDIAN \\ RANGE OF MOTION (ROM) APLIKASI KETERAMPILAN \\ TANGAN BAGI LANSIA PREVENTIF REUMATOID ARTHRITIS DI PSTW
}

Chairil*, Isnaniar ,Wiwik norlita, Juli widiyanto,Tri Siwi KN, Maswarni , Pratiwi Gasril

D III Keperawatan Fakultas Mipa Dan Kesehatan

*Email: Chairil@Umri.ac.id

\begin{abstract}
ABSTRAK
Proses penuaan secara alami pasti terjadi sesuatu hal yang harus di cermati bagaimana di hari tua hidup sehat dan kriatif itu tidak semua lansia bisa menjalaninya salah diantaranya adalah kurangnya gerakanyang di lakukan lansia tujuan IbM ini memberikan aplikasi gerakan rom untuk kratipitas keterampilan tangan sasaran lansia yang mengalami Reumatoid Arhritis dan mau untuk melakukan gerakan dalam bentuk kerajinan tangan hal ini di pandang penting di sebabkan satu diantaranya jenis penyakit yang ada adalah Rheumatoid arthritis.Rheumatoid arthritis adalah peradangan kronis pada sendi yang menyebabkan rasa sakit,bengkak dan kaku pada persendian contohnya di kaki dan tangan.Arthritis berarti radang sendi dan bisa berdampak pada jaringan di sekitar persendian, seperti pada otot, ligamen, dan tendon. Seiring waktu, peradangan ini bisa menghancurkan jaringan persendian. Efek dari kondisi ini akan membatasi aktivitas keseharian, seperti sulit untuk berjalan dan menggunakan tangan. Perawatan rheumatoid arthritis yang dapat dilakukan adalah dengan melakukan terapi satu diantaranya dengan ROM serta pengobatan jangka panjang untuk menghambat perkembangan dan gejala rheumatoid arthritis. Jika perawatan dengan terapi dan pengobatan sudah tidak efektif, untuk memperbaiki masalah persendian dapat dilakukan. Latihan range of motion (ROM) adalah latihan yang dilakukan untuk mempertahankan atau memperbaiki tingkat kesempurnaan kemampuan menggerakan persendian secara normal dan lengkap untuk meningkatkan massa otot dan tonus otot. Aktivitas adalah suatu energy atau keadaan bergerak dimana manusia memerlukan untuk dapat memenuhi kebutuhan hidup
\end{abstract}

Kata Kunci $\quad$ : Rheumatoid arthritis, melakukan gerakan ROM

\section{PENDAHULUAN}

Usia lanjut adalah suatu kejadian yang pasti akan dialami oleh semua orang, terjadinya tidak bisa dihindari oleh siapapun dan dapat terjadi berbagai kemunduran pada organ tubuh. Pada periode ini kemampuan jaringan untuk memperbaiki diri ataupun mengganti dan mempertahankan fungsi normalnya akan perlahan-lahan menurun (Admin, 2010).
Masalah lansia sebenarnya merupakan mekanisme evolusi kehidupan alam, dimana akan terjadi regenerasi kehidupan. Permasalah yang sering terjadi pada lansia biasanya disebabkan proses penuaan, satu diantaranya adalah kurangnya gerakan pada daerah persendian/aktivitas tubuh (Fauziah, 2013). Salah satu penyakit yang sering terjadi adalah Rheumatoid arthritis atau artritis reumatoid adalah peradangan kronis pada sendi 
yang menyebabkan rasa sakit, bengkak dan kaku pada persendian contohnya di kaki dan tangan.

Arthritis berarti radang sendi dan bisa berdampak pada jaringan di sekitar persendian, seperti pada otot, ligamen, dan tendon. Seiring waktu, peradangan ini bisa menghancurkan jaringan persendian. Efek dari kondisi ini akan membatasi aktivitas keseharian, seperti sulit untuk berjalan dan menggunakan tangan. Penderita rheumatoid arthritis hanya bisa melakukan perawatan karena hingga saat ini masih belum ada obat yang dapat menyembuhkan rheumatoid arthritis secara total, namun dengan perawatan yang tepat, penyebaran dan peradangan dapat dihambat.

Perawatan rheumatoid arthritis yang dapat dilakukan adalah satu diantaranya Latihan range of motion (ROM) adalah latihan yang dilakukan untuk mempertahankan atau memperbaiki tingkat kesempurnaan kemampuan menggerakan persendian secara normal dan lengkap untuk meningkatkan massa otot dan tonus otot. Aktivitas adalah suatu energy atau keadaan bergerak dimana manusia memerlukan untuk dapat memenuhi kebutuhan hidup (Verar, 2013).

Sekitar $43 \%$ lansia telah diidentifikasi memiliki gaya hidup kurang gerak.Untuk mengatasi hal ini diperlukan di upayakan meningkatkan ruang gerak (ROM) pada lansia. Range of motion (ROM) yaitu kemampuan klien untuk menggerakkan sendi agar tidak terjadi kekakuan, pembengkakan, nyeri, keterbatasan sendi dan gerakan yang tidak seimbang (Wahyudi, 2008). Gerakkan di aplikasikan dalam bentuk keterampilan tangan di samping lansia dapat mengurangi nyeri yang dirasakan dari gejala arthritis dan menghasilan kerajinan tangan seperti mainai anak-anak sapu, gelang dan lain -lain hal ini bisa menjadi sopetir bagi penggjung di pstw khsunul khotimah

Perumusan masalah Berdasarkan permasalahan di atas dapat di rumuskan adalah untuk memberikan gambaran solusi penderita reumatoid arthritis dengan gerakan persendian range of motion (rom) dengan aplikasi keterampilan tangan di pstw khusnul khotimah

Tujuan Untuk dapat meningkatkan tarap hidup sehat bagi penderita Reumatoid arthritis dengan melakuakan gerakan rom dengan aplikasi keterampilan tangan Menciptakan suasana yang aman di lingkungan sekitar Memeliki perilaku yang baik dan mampu memberikan percontohan bagi lansia lain

\section{MATERI DAN METODE}

Pada kegiatan ini akan di laksanankan melalui pemberian contoh kerajinan pembuatan ayaman sapu, pembuatan kalu dan permainan anak -anak dalam bentuk latihan gerak pada lansia di PSTW khusnul khotimah tentang preventif rheumatoid arthritis dengan rom (range of motion) di rencanakan yang akan dilakasanakan selama dua bulan Desember 2016 sampai Januari 2017 pertemuan dan latian kerajianan dan gerakan di rencanakan 29.30 dan 31 Januari 2017 dimana setiap pertemuan dilaksanakan selama 2 jam, namun apabila masih diperlukan maka akan dilakukan penambahan waktu. kegiatan ini bertujuan untuk meningkatkan kesehatan lansia dan 
memberikan pemahaman latihan gerakan persendia dan keterampilan tangan pada lansia Pada akhir kegiatan di lakukan diskusi kelompok dan permasalah yang ada di selesaikan dengan pengulangan materi dan memberikan tanggung jawab kepada lansia yang pahan kepada temannya yang belum paham

\section{HASIL DAN PEMBAHASAN}

Pelaksanaan kegiatan pengabdian dilaksanakan di dari tanggal dua bulan Desembe dan Januari 2017. Rancangan kegiatan dilakukan beberapa tahap, tahap persiapan pengajuan proposal kegiatan dimulai dari tanggal 28 November 2016. Tahap pengkajian permasalahan kesehatan penduduk dimulai pendataan pada tanggal 15-16 Desember 2016. Tahap dan penyuluhan dan latihan gerak kepada penduduk dilaksanakan 29,30 Januari 2017. Kegiatan ini di ikuti oleh 10 orang lansia

Adapun materi yang dapat di berikan

- Pengaertian : gerakan senam jari tangan yang diperuntuhkan untuk lansia menggunakan bola kasti yang dibagi dua atau utuh

- Tujuan : Aplikasi gerakan persendian R.O.M untuk Keterampilan

- Peralatan : bola kasti / 1/2 bola kasti

Prosedure : A. Tahan Interaksi

1. Memberikan Salam sebagai pendekatan Terapiutik

2. Menjelaskan tujuan dan Prosedur senam jari tangan untuk lansia

\section{Tahap Kerja}

1. Bagikan Bola kasti/ $1 / 2$ bola kasti kepada setiap lansia yang akan melaksanakan senam

2. Luruskan kedepan kedua tangan yang sedah memegang bola (jika mampu meluruskan tangan).

3. Kemudian lakukan gerakan menggenggam pada bola

4. Kemudian lakukan gerakan menggenggam kuat dan longgarkan sebanyak 5-10 kali dan dilakukan sebanyak 10 kali

5. Lakukan gerakan dengan nyaman dan santai tanpa terburu-buru

\section{Tahap Terminasi}

1. Mengevaluasi kegiatan

2. Merapikan tempat kegiatan

3. Berpamitan dengan lansia

4. Melakukan dokumentasi kegiatan

Pengaertian : gerakan senam jari tangan yang diperuntuhkan untuk lansia

- Tujuan : Aplikasi gerakan persendian R.O.M untuk Keterampilan

- Peralatan : Koran

- Prosedure : Tahan Interaksi

1. Memberikan Salam sebagai pendekatan Terapiutik

2. Menjelaskan tujuan dan Prosedur senam jari tangan untuk lansia

\section{Tahap Kerja}

1. Bagikan Koran kepada setiap lansia yang akan melaksanakan senam

2. Luruskan kedepan kedua tangan yang sedah memegang koran (jika mampu). 
ISSN : 2550-0198

3. Kemudian lakukan gerakan ingin menggenggam yang dilakukan oleh sendi paling ujung jari tangan

4. Lakukan secara perlahan gerakan ingin menggenggam sampai akhirnya tergenggam penuh.

\section{Tahap Terminasi}

1. Mengevaluasi kegiatan

2. Merapikan tempat kegiatan

3. Berpamitan dengan lansia

4. Melakukan dokumentasi kegiatan

Pada tahap awal permasalahan secara umum terdapat beberapa hal diantaranya:

1. Kekuatan

a. Kerjasama yang baik antara sesama teman sejawat

b. Informasi, arahan ketua LP2K

c. Koordinasi yang baik antara pemberi penyuluhan dan petugas kesehatan di lansia

2. Kelemahan

Keterbatasan dana yang tersedia untuk melakukan kegiatan ini

3. Kesempatan

Adanya dukungan dari lintas program dan lintas sektoral

\section{Tahap Pengkajian}

Pada tahap ini dapat
diidentifikasi:

1. Kekuatan

a. Pengkajian dapat dilaksanakan atas adanya kerjasama untuk melakukan pendataan atau mengumpulkan data di lapangan.

b. Adanya dukungan dari aparat petugas lansia

c. Adanya keterangan dari petugas lansia d. Kesediaan lansia untuk menerima informasi

\section{Kelemahan}

Sebagian besar lansia mengalami masalah pendengar sehingga mengalami kesulitan dalam penyampaian

\section{Kesempatan}

Dukungan dari lintas sektoral dan lintas program dalam pelaksanaan kegiatan

\section{Ancaman}

Kurangnya pengetahuan dari lansiat tentang latian rom dan reumatoid arthitis

\section{Tahap Intervensi}

1. Kekuatan

a. Tahap perencanaan dapat dilaksanakan karena telah terbinanya kerja sama yang baik antara pemberi materi dengan lansia dengan 10 orang lansia

b. Dalam penyusunan rencana tindakan penyuluahan latian gerak rom dan aplikasi gerakan adanya kesepakatan bersama antara pemberi dengan lansia petugas setempat.

2. Kelemahannya

Mayoritas pemahaman lansia terhadap masalah kesehatan masih kurang. Dan gerakan rom

\section{Kesempatan}

Adanya dukungan dan kerja sama yang baik antara pemberi dengan petugas kesehatan serta lansia dan akan terus di lakuan pembinaan

4. Ancaman

Lansia tidak mampu untuk mengenal tanda reumatoid arthritis dan latihan gerakan rom dan memecahkan masalah kesehatan yang ada disekitar.

\section{Tahap Implementasi}

1. Kekuatan 
a. Adanya kerja sama yang baik dengan masyarakat setempat.

b. Adanya petugas aktif dalam membantu pelaksanaan kegiatan

c. Adanya partisipasi dari lansia

2. Kelemahan

a. Mayoritas pemahaman lansia terhadap masalah kesehatan masih kurang.

b. Pelaksanaan kegiatan sering terlambat dari jadwal yang telah ditentukan.

c. Sulitnya mengumpulkan lansia dalam waktu tertentu.

3. Kesempatan

a. Pelaksanaan ini dapat dilaksanakan karena adanya dukungan lintas sektoral dan lintas program.

b. Banyaknya permintaan lansia untuk meningkatkan frekuensi kegiatan penyuluhan.

4. Ancaman

Kurang optimalnya dalam pelaksanaan kegiatan. dan latian rom maupun kerajianan

\section{Tahap Evaluasi}

1. Kekuatan

a. Adanya kerjasama antar masyarakat dan pemberi penyuluhan untuk menetapkan kriteria pencapaian tujuan.

b. Adanya peran serta yang aktif dari lansia untuk melaksanakan kegiatan pencapaian tujuan.

2. Kelemahan

Adanya kegiatan lansia yang belum menyadari dan kurang termotivasi dalam melaksanakan kegiatan untuk mengatasi permasalahan kesehatan sesuai dengan kriteria yang diharapkan.

3. Kesempatan

a. Adanya bantuan dan partisipasi pihak petugas dalam mengarahkan kegiatan yang

dilaksanakan .

b. Adanya dukungan dari lintas sektoral dan lintas program kesinambungan kegiatan

\section{Ancaman}

Kurang optimal pelaksanaan kegiatan yang dilakukan.

Setelah melakukan identifikasi permasalahan kesehatan, maka dapat dilakukan analisa terhadap permasalahan kesehatan tersebut yang mencakup kekuatan, kelemahan, serta kesempatan dan berbagai kelompok lansia permasalahan antara lain dalam memberikan atau Mengadakan penyuluhan dan latian gerakan rom dam pemberian materi rheumatoid arthritis ;

\section{Kekuatan}

Adanya kerjasama yang baik antara pemberi penyuluhan dengan lansia dalam melaksanakn kegiatan untuk mengatasi masalah kesehatan .

2. Kelemahan

Kurangnya motivasi dari sebagian lansia untuk mengikuti kegiatan dalam upaya mengatasi masalah kesehatan .

\section{Kesempatan}

Adanya waktu yang tersedia dari lansia untuk melakukan kegiatan dalam mengatasi masalah kesehatan

4. Ancaman

Timbulnya penyakit akibat kurangnya gerakan dan perilaku yang kurang sehat.

\section{KESIMPULAN}

Permasalah yang sering terjadi pada lansia biasanya disebabkan proses penuaan, salah satunya adalah kurangnya gerakan pada daerah persendian/aktivitas tubuh. Salah satu jenis penyakit yang ada adalah Rheumatoid arthritis.Rheumatoid 
ISSN : 2550-0198

arthritis adalah peradangan kronis pada sendi yang menyebabkan rasa sakit,bengkak dan kaku pada persendian contohnya di kaki dan tangan.Arthritis berarti radang sendi dan bisa berdampak pada jaringan di sekitar persendian, seperti pada otot, ligamen, dan tendon. Seiring waktu, peradangan ini bisa menghancurkan jaringan persendian. Untuk itu perlu di cari solusinya satu di antaranya dengan ROM

Range of motion (ROM) yaitu kemampuan klien untuk menggerakkan sendi agar tidak terjadi kekakuan, pembengkakan, nyeri, keterbatasan sendi dan gerakan yang tidak seimbang .ROM dibagi menjadi 2, yaitu ROM aktif dan ROM pasif.Tujuan dari latihan ROM ini adalah Mempertahankan/memelihara

fleksibilitas dan kekuatan otot, Memelihara mobilitas persendian, Merangsang sirkulasi darah, dll. Sedankan manfaatnya adalah . Memperbaiki tonus otot, Meningkatkan mobilisasi sendi, Memperbaiki toleransi otot untuk latihan, dan Meningkatkan massa otot.

\section{UCAPAN TERIMAKASIH}

Terima kasih kepada semua teman-teman sejawat yang telah ikut serta di dalam pengabdian Masyarakat di PSTW Khusnul Lhotimah Pekanbaru yang telah memberikan tempat dan membantu semaua ademinitrasi demi berlansungnya kegiatan ini, dan terimah kasih pada pimpinan Lp2M dan staf yang membantu dalam media pendanan dan ademistrasi dalam pengurusuan pengabdian

\section{DAFTAR PUSTAKA}

[1] Azizah,Lilik

Ma'rifatul.

Keperawatan Lanjut Usia.

Edisi 1. Garaha

Ilmu.Yogyakarta. 2011

[2] Admin.(2010). Hubungan

Kondisi Fisik RTT Lansia

Terhadap Kondisi Sosial

Lansia di RW 03 RT 05

Kelurahan Tegalsari

Kecamatan

Candisari.http://eprints.undip.a

c.id. Diperoleh pada tanggal 23

Desember 201

[3] Admin.(2012). Olahraga Untuk Lansia.http://www.lkc.or.id.

Diperoleh pada tanggal 19

Desember 2013

[4] Brooker Chris.(2008).

Ensiklopedia

Keperawatan.http://books.goog

le.co.id. Diperoleh pada

tanggal 23 Desember 2013

[5] Dek Oka. (2013). Range Of Motion

(ROM).http://www.slideshare.

net. Diperoleh pada tanggal 19

Desember 2013

[6] Doenges E Marilynn. 2000.

Rencana Asuhan Keperawatan.

EGC: Jakarta

[7] Fauziah Reni Rn. (2013).

Kualitas Tidur Pada Lansia. http://www.slideshare.net.

Diperoleh pada tanggal 23

Desember 2013

Fitriyani Dewi. (2013). Defenisi ROM.

http://www.slideshare.net.

Diperoleh pada tanggal 19

Desember 2013

[8] Suratun, dkk. (2006). Klien Gangguan Sistem

Muskuloskeletal. Jakarta : EGC

[9] Verar.(2013). Range Of Motion

(ROM).http://www.slideshare. 
net. Diperoleh pada tanggal 23

Desember 2013

[10] Wahyudin, N. (2008).

Keperawatan Gerontik \&

Geriatric. Jakarta : EGC

[11] Kushariyadi. Asuhan

Keperawatan pada Klien

Lanjut Usia. Salemba Medika.

Jakarta. 2010

[12] Mubaraq, Chayatin, Santoso.

Ilmu Keperawatan Komunitas

Konsep Dan Aplikasi. Salemba Medika. Jakarta. 2011

[13] Stanley, Mickey. Buku Ajar Keperawatan Gerontik. Alih Bahasa; Nety Juniarti, Sari Kurnianingsih. Editor; Eny Meiliya, Monica Ester. Edisi 2. EGC. Jakarta. 2006

[14] Tamher, S. Noorkasiani. Kesehatan Usia Lanjut dengan Pendekatan Asuhan Keperawatan. Salemba Medika. Jakarta. 2011 